\title{
Aerobic and Anaerobic Bacterial Respiration Monitored by Electrodes
}

\author{
By P. JOHN \\ Botany School, University of Oxford, South Parks Road, Oxford OXI $3 R A$
}

(Received 12 July 1976)

SUMMAR Y

\begin{abstract}
A technique is described by which both oxygen and nitrate (or nitrite or chlorate) levels were continuously monitored during bacterial respiration. Paracoccus (Micrococcus) denitrificans and Escherichia coli oxidizing succinate rapidly ceased to reduce nitrate when oxygen was available, and equally rapidly commenced nitrate reduction when all the oxygen had been consumed. By contrast, membrane vesicles isolated from $P$. denitrificans reduced oxygen and nitrate simultaneously. The respiratory nitrate reductase in intact cells of $P$. denitrificans appeared to be inaccessible to chlorate present in the reaction medium, and it is suggested that the nitrate reductase is orientated on the plasma membrane so that nitrate gains access from the inner (cytosolic) face.
\end{abstract}

\section{INTRODUCTION}

A wide variety of bacteria can use either oxygen or nitrate as alternative terminal electron acceptors during respiration. Some bacteria such as Escherichia coli (KI2) reduce nitrate only to nitrite, while others, such as Paracoccus denitrificans (formerly Micrococcus denitrificans, Davis et al., 1969), reduce nitrate via nitrite to dinitrogen gas. In both types of bacteria the respiratory nitrate reductase is located in the plasma membrane and is linked to the constitutive, aerobic respiratory chain in the region of the $b$-type cytochromes (see reviews by White \& Sinclair, 197I ; Payne, 1973).

Oxygen represses the synthesis of the nitrate reductase and also inhibits intracellular nitrate reduction. This inhibitory effect on nitrate respiration appears to be indirect, since the isolated respiratory nitrate reductase is unaffected by oxygen (Payne, 1973). Although it has been known for many years (see Delwiche, 1956) that bacteria adapted to use nitrate require anaerobiosis to carry out nitrate respiration, little is known of the biochemical mechanisms by which reducing equivalents are directed preferentially to oxygen rather than to nitrate.

In the present paper, studies of aerobic and anaerobic respiration by intact cells of $P$. denitrificans and $E$. coli $\mathrm{KI} 2$ and by membrane preparations of $P$. denitrificans are described. A new technique has been used by which oxygen and nitrate (or nitrite or chlorate) levels were continuously and simultaneously monitored by the use of electrodes.

\section{METHODS}

Bacteria. Paracoccus denitrificans NCIB8944 was grown with succinate as substrate and nitrate as the added terminal electron acceptor as described by Burnell, John \& Whatley (1975). Escherichia coli KI2 (strain W3 I IO, supplied by Dr M. Yudkin) was grown in a medium which contained ( $\left.\mathrm{g} \mathrm{l}^{-1}\right)$ : Difco Bacto-peptone, 4; yeast extract, $2 ; \mathrm{K}_{2} \mathrm{HPO}_{4}$, I0; 
$\mathrm{KNO}_{3}, \mathrm{IO} \cdot \mathrm{I}$; and sodium succinate. $6 \mathrm{H}_{2} \mathrm{O}, \mathrm{I} 3.5$. The $\mathrm{pH}$ was adjusted to 6.8 with $\mathrm{H}_{2} \mathrm{SO}_{4}$. The growth conditions were as described for $P$. denitrificans.

In experiments using intact bacteria, cultures of $P$. denitrificans and $E$. coli at the midexponential and.stationary phases, respectively, were harvested by centrifuging at $5000 \mathrm{~g}$ for $30 \mathrm{~min}$ at 0 to $4{ }^{\circ} \mathrm{C}$, washed twice in $200 \mathrm{~mm}$-sucrose containing $10 \mathrm{mM}$-Tris/ $\mathrm{HCl}(\mathrm{pH}$ $8 \cdot 0$ ) at 0 to $4{ }^{\circ} \mathrm{C}$, and then suspended to a final concentration of 20 to $80 \mathrm{mg} \mathrm{dry} \mathrm{wt} \mathrm{ml}^{-1}$ in $200 \mathrm{~mm}$-sucrose containing Io mM-Tris/ $\mathrm{HCl}\left(\mathrm{pH} \mathrm{8.0)}\right.$ ) at o to $4{ }^{\circ} \mathrm{C}$. Membrane vesicles were prepared from $P$. denitrificans as described by Burnell et al. (1975), except that Io mM-ATP $\left(\mathrm{pH} 7{ }^{\circ} 0\right)$ was included in the $100 \mathrm{mM}$-Tris/acetate buffer in which the lysozyme-treated cells were resuspended.

Simultaneous determinations of oxygen and nitrate (or nitrite or chlorate). Changes in the concentrations of oxygen and nitrate were measured simultaneously in a $50 \mathrm{ml}$ reaction vessel equipped with a Clark-type oxygen electrode and a liquid membrane nitrate electrode (model 92-07; Orion Research, Cambridge, Massachusetts, U.S.A.). The changes were recorded continuously on a twin-channel, potentiometric recorder (Servoscribe 2; Smiths Industries, Wembley, Middlesex). The oxygen electrode was constructed by $\mathrm{Mr}$ M. J. Fowler of the Biochemistry Department, Bristol University. The concentration of oxygen in air-saturated water at $30{ }^{\circ} \mathrm{C}$ was taken to be $0.47 \mu \mathrm{g}$-atom ml $\mathrm{m}^{-1}$ (Kaye \& Laby, 1966).

Under the appropriate conditions (see below) the nitrate electrode could also be used to measure nitrite or chlorate.

The potential developed by the nitrate electrode was measured against a double junction reference electrode (model 90-02; Orion Research) using a $\mathrm{pH}$ meter (model 292; Pye Unicam) set on the $\mathrm{mV}$ mode, and connected in parallel with a roo $\Omega$ resistor to one channel of the recorder. The reaction chamber was constructed of Perspex. It was maintained at $30{ }^{\circ} \mathrm{C}$ by a jacket of circulating water and was closed from the atmosphere except for a hole of I $\mathrm{mm}$ diam. through which additions could be made with a syringe. To minimize 'noise' due to static electricity, the exposed parts of the nitrate electrode and its reference electrode were covered in aluminium foil, and all the electrodes and the reaction chamber were treated with gramophone record antistatic agent. The noise level tolerated did not exceed $\mathrm{I} \%$ of a full-s cale deflexion. The reaction mixture was stirred magnetically.

Protein was determined by the method of Lowry et al. (I95I) with bovine serum albumin as standard.

Reagents. Gramicidin D and all enzymes and coenzymes were purchased from Sigma. All other reagents were of analytical grade.

\section{RESULTS AND DISCUSSION}

\section{Response of the nitrate electrode to nitrate, nitrite, chlorate and chlorite}

The nitrate electrode was used to measure the concentration of nitrate, nitrite or chlorate when these anions were added singly as terminal electron acceptors. However, measurements of nitrate reduction were not affected significantly by the nitrite which accumulated in the absence of concurrent nitrite reduction, nor were measurements of chlorate reduction affected significantly by the accumulation of chlorite. Intact bacteria or membrane vesicles were allowed to reduce nitrate, nitrite or chlorate from an initial concentration of $5 \mathrm{~mm}$ to a final concentration of approximately $4 \mathrm{mM}$. This concentration change was arranged to give almost full-scale deflexion of the recorder.

The nitrate electrode could be used to monitor changes in the concentration of nitrate (Fig. I $a$ ), nitrite (Fig. I $c$ ), chlorate (Fig. I $e$ ) and chlorite (Fig. I $g$ ). The sensitivity of the 

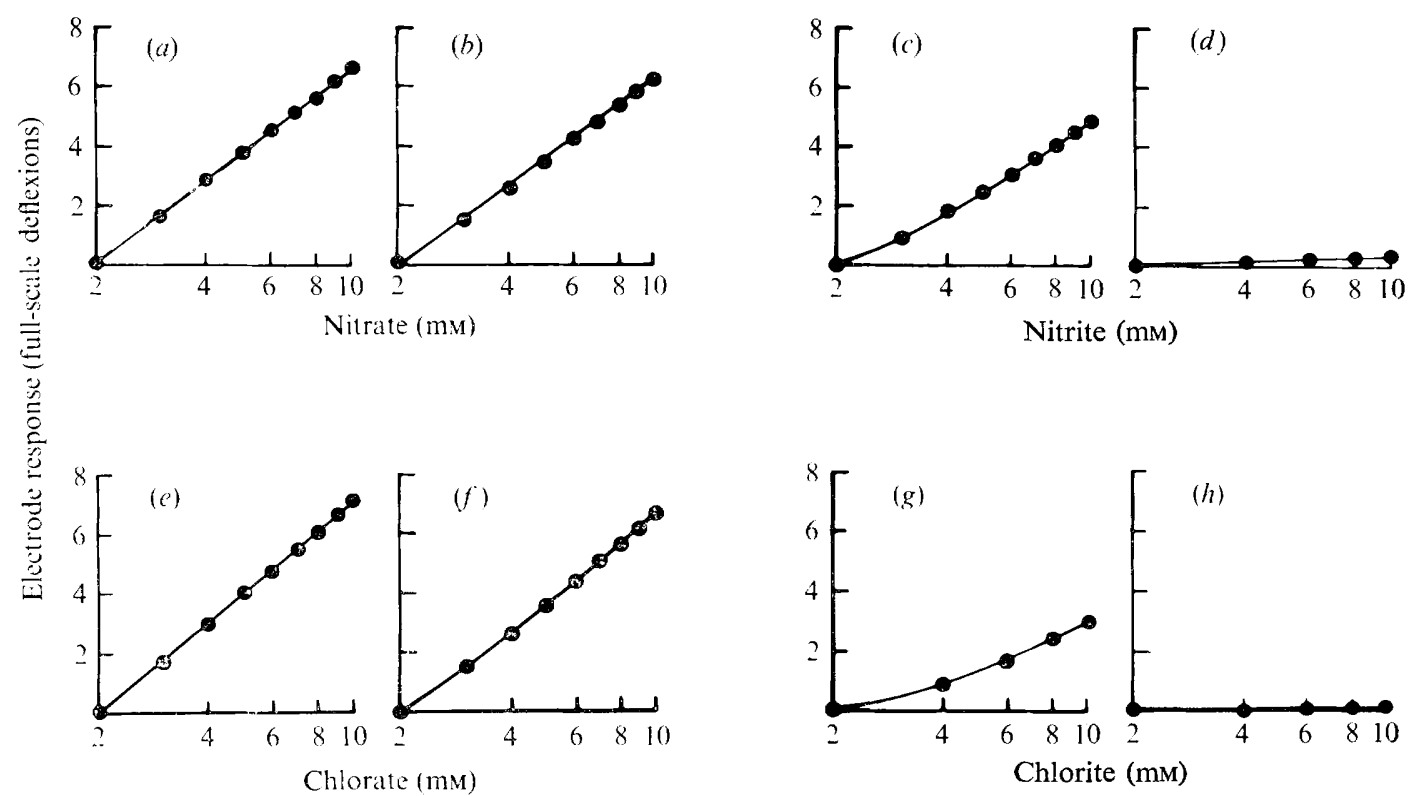

Fig. I. Response of the nitrate electrode to nitrate, nitrite, chlorate and chlorite; the electrode was exposed to $50 \mathrm{ml} 20 \mathrm{~mm}$-Tris/ $\mathrm{HCl}\left(\mathrm{pH} 8.0\right.$ ) containing: (a) $2 \mathrm{~mm}-\mathrm{NaNO}_{3},(b) 2 \mathrm{~mm}-\mathrm{NaNO}_{3}$ plus

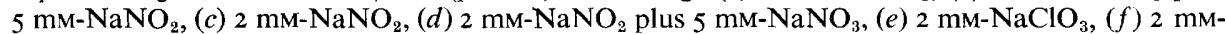
$\mathrm{NaClO}_{3}$ plus $5 \mathrm{~mm}-\mathrm{NaClO}_{2},(g) 2 \mathrm{~mm}-\mathrm{NaClO}_{2}$, $(h) 2 \mathrm{~mm}-\mathrm{NaClO}_{2}$ plus $5 \mathrm{~mm}-\mathrm{NaClO}_{3}$. Successive additions $\left(50\right.$ or $100 \mu$ ) of $1 \mathrm{M}-\mathrm{NaNO}_{3}(a, b)$, I $\mathrm{M}-\mathrm{NaNO}_{2}(c, d)$, I $\mathrm{M}-\mathrm{NaClO}_{3}(e, f)$ or I $\mathrm{M}-\mathrm{NaClO}_{2}$ $(g, h)$ were made as indicated and the resulting deflexions of the recorder were noted.

electrode to these anions is given by the slopes of the graphs in Fig. $\mathrm{I}$ and was in the order: $\mathrm{NO}_{3}{ }^{-}=\mathrm{ClO}_{3}{ }^{-}>\mathrm{NO}_{2}^{-}>\mathrm{ClO}_{2}^{-}$. In the presence of $5 \mathrm{~mm}$-nitrate, the electrode response to increasing concentrations of nitrite was negligible (Fig. I $d$ ). Similarly, in the presence of $5 \mathrm{~mm}$-chlorate, the electrode response to increasing concentrations of chlorite was negligible (Fig. $\mathrm{I} h$ ). The fortunate consequence of this selectivity of the nitrate electrode for nitrate over nitrite and for chlorate over chlorite was that accumulating nitrite (or chlorite) did not interfere with measurements of nitrate (or chlorate) reduction, while the electrode was sufficiently sensitive to nitrite for measurements of nitrite reduction to be made in the absence of nitrate.

Although the nitrate electrode responded exponentially to linear changes in the concentrations of nitrate, nitrite or chlorate (Fig. 1), a maximum error of only $5 \%$ was incurred by assuming a linear response over the limited concentration range employed ( $5 \mathrm{~mm}$ decreasing to $4 \mathrm{~mm}$ ). To ensure that changes during the course of the reaction, and additions to the reaction mixture, did not interfere with the response of the nitrate electrode, calibrating additions of nitrate, nitrite or chlorate were made before and after the reaction, as shown in Fig. 2.

\section{Utilization of nitrate and nitrite by $P$. denitrificans}

When intact cells of $P$. denitrificans were added to an aerobic medium containing nitrate, they utilized oxygen but did not utilize nitrate until all the oxygen present had been used up, at which time nitrate reduction commenced (Fig. 2). When oxygen was reintroduced into the medium, nitrate reduction ceased immediately and oxygen again became the sole terminal electron acceptor utilized. The inhibitory effect of oxygen on nitrate reduction could be shown repeatedly (Fig. 2). The initial, rapid deflexion of the recorder pen when the bacteria 


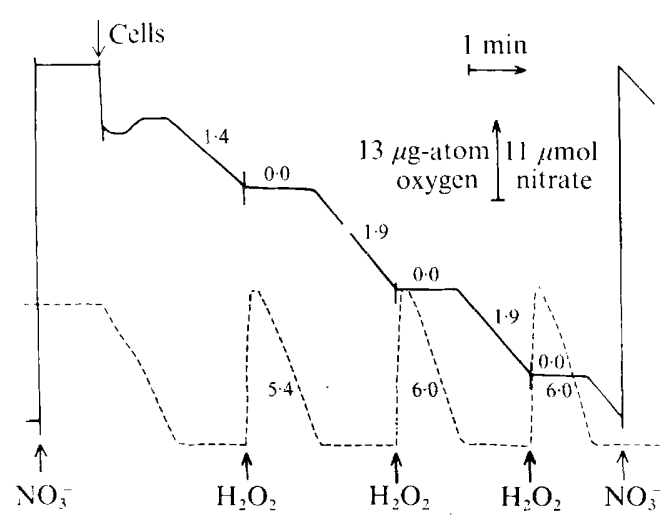

Fig. 2

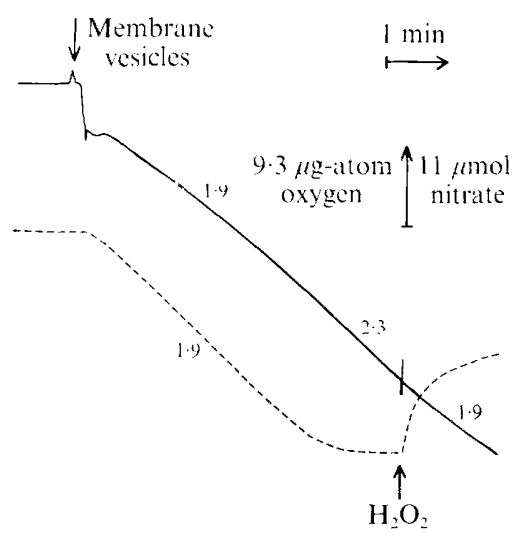

Fig. 3

Fig. 2. Reduction of oxygen and nitrate by $\boldsymbol{P}$. denitrificans. To a reaction mixture containing $200 \mathrm{~mm}$-sucrose, $20 \mathrm{~mm}$-Tris $/ \mathrm{HCl}\left(\mathrm{pH} 8.0\right.$ ), Io mm-sodium succinate, $4 \mathrm{~mm}-\mathrm{NaNO}_{3}$ and $5 \mu \mathrm{l}$ catalase (Sigma C-IOO) were added $50 \mu \mathrm{l}$ I $\mathrm{M}-\mathrm{NaNO}_{3}, 2 \mathrm{ml}$ cell suspension (containing $96 \mathrm{mg}$ dry wt bacteria) and $\mathrm{H}_{2} \mathrm{O}_{2}$ as indicated. The rates of reduction given alongside the traces are expressed in $\mu$ g-atom oxygen $\mathrm{s}^{-1}(\mathrm{~g} \text { dry } \mathrm{wt})^{-1}\left(--_{-}\right)$and $\mu \mathrm{mol}$ nitrate $\mathrm{s}^{-1}(\mathrm{~g} \text { dry } \mathrm{wt})^{-1}(\longrightarrow)$.

Fig. 3. Reduction of oxygen and nitrate by membrane vesicles of $\boldsymbol{P}$. denitrificans. To a reaction mixture containing $20 \mathrm{~mm}$-Tris/ $\mathrm{HCl}(\mathrm{pH} 8.0), 30 \mathrm{~mm}$-ammonium acetate, $0.5 \mu \mathrm{g}$ gramicidin $\mathrm{D}$,

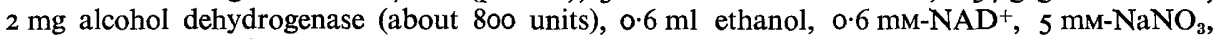
and $5 \mu \mathrm{l}$ catalase (Sigma $\mathrm{C}$ - $\mathrm{IOO}$ ) were added $0.8 \mathrm{ml}$ of a suspension of membrane vesicles (containing $3.5 \mathrm{mg}$ protein) and $\mathrm{H}_{2} \mathrm{O}_{2}$ as indicated. The rates of reduction given alongside the traces are expressed in $\mu$ g-atom oxygen $\min ^{-1}(\mathrm{mg} \text { protein })^{-1}(--)$ and $\mu$ mol nitrate $\mathrm{min}^{-1}$ (mg protein $)^{-1}(-)$.

were added to the reaction medium (as seen in Fig. 2 and subsequent nitrate electrode traces) is due largely to the dilution of the nitrate by the cell suspension. The rate of oxygen uptake

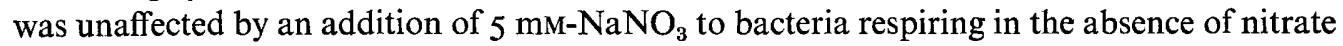
(other conditions as in Fig. 2).

Samples of the reaction mixture assayed for nitrite colorimetrically by the Griess-Ilosvay reaction (John \& Whatley, 1970) showed that less than $10 \%$ of the nitrate reduced was recoverable as nitrite. Thus more than $90 \%$ of the nitrate reduced by $P$. denitrificans under conditions similar to those described for Fig. 2 was reduced further than nitrite. During nitrate reduction there was, therefore, a similar rate of nitrite reduction. The nitrite reductase of $P$. denitrificans appears to accept reducing equivalents from the aerobic respiratory chain (see John \& Whatley, 1975) in the region of the $c$-type cytochromes (Newton, I969; Lam \& Nicholas, 1969). Although the $c$-type cytochromes may be oxidized either by oxygen via cytochrome oxidase, or by nitrite via the nitrite reductase, nitrate reduction ceases only when oxygen is the terminal electron acceptor; nitrite and nitrate reduction can occur simultaneously.

When nitrite $(5 \mathrm{~mm})$ was present in the reaction medium instead of nitrate (other conditions as in Fig. 2), nitrite reduction [3 to $4 \mu \mathrm{mol} \mathrm{s}^{-1}$ (g dry wt) ${ }^{-1}$ ] was observed only when the reaction medium was depleted of oxygen.

Membrane vesicles prepared from the plasma membrane of $P$. denitrificans broken by osmotic lysis retain the ability to reduce oxygen and nitrate, but are unable to reduce nitrite, presumably because the nitrite reductase is lost from the membranes during their isolation (John \& Whatley, 1970). When these membrane vesicles were added to an aerobic medium containing nitrate, they utilized both oxygen and nitrate simultaneously and when oxygen 


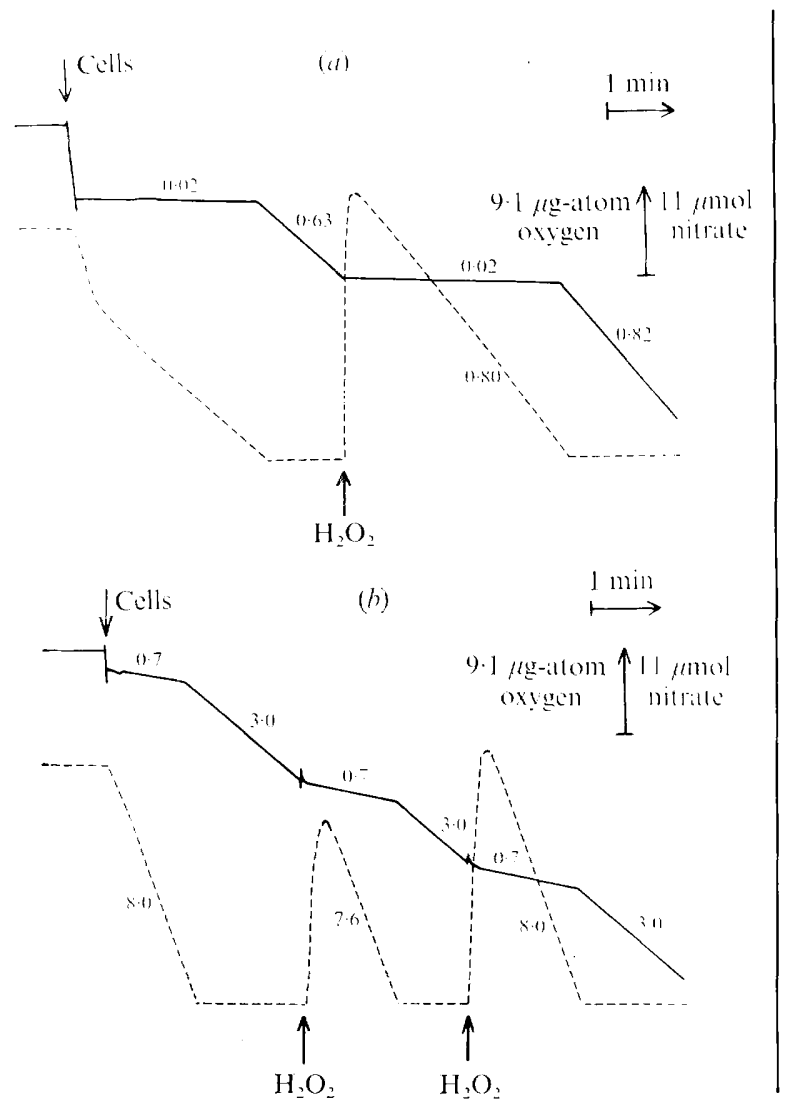

Fig. 4

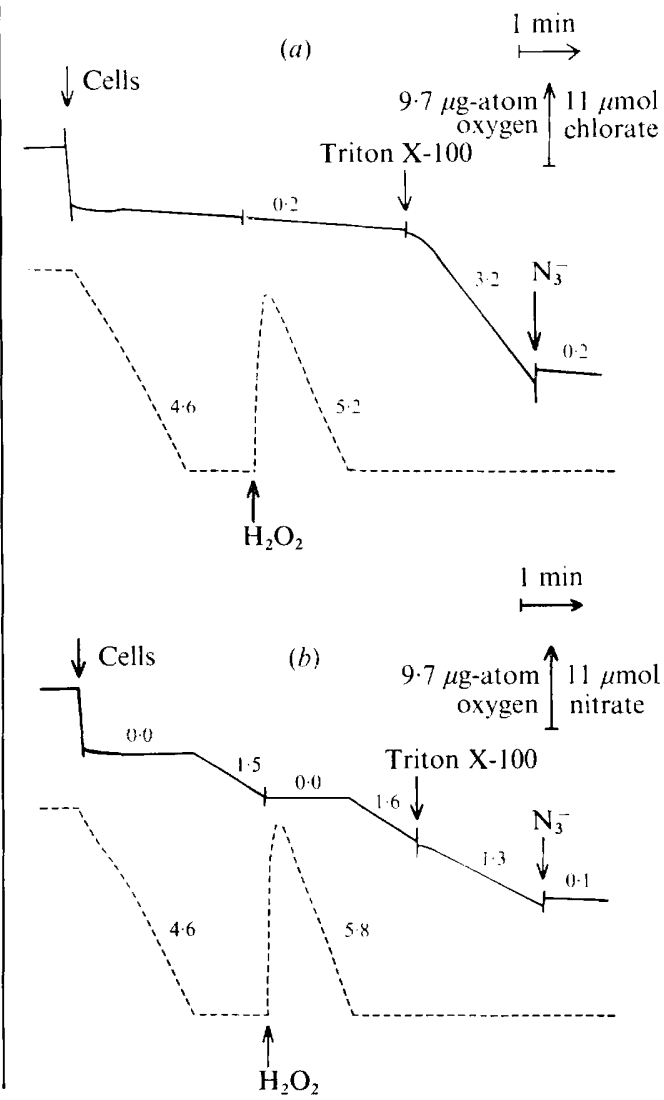

Fig. 5

Fig. 4. Reduction of oxygen and nitrate by $E$. coli. The reaction mixture contained $200 \mathrm{~mm}$-sucrose,

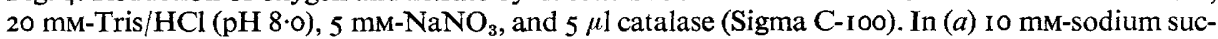
cinate was included as substrate, and $2.5 \mathrm{ml}$ cell suspension (containing $215 \mathrm{mg}$ dry wt bacteria) was added. In $(b)$ io mM-sodium formate was included as substrate, and $0.5 \mathrm{ml}$ cell suspension (containing $43 \mathrm{mg}$ dry wt bacteria) was added. The rates of reduction given alongside the traces are expressed in $\mu \mathrm{g}$-atom oxygen $\mathrm{s}^{-1}(\mathrm{~g} \text { dry } \mathrm{wt})^{-1}(---)$ and $\mu \mathrm{mol}$ nitrate $\mathrm{s}^{-1}(\mathrm{~g} \text { dry wt })^{-1}(--)$.

Fig. 5. Comparison of nitrate and chlorate reduction by $P$. denitrificans. The reaction mixture contained $200 \mathrm{~mm}$-sucrose, $20 \mathrm{~mm}-\mathrm{Tris} / \mathrm{HCl}(\mathrm{pH} 8 \cdot 0)$, Io mM-sodium succinate, and $5 \mu$ l catalase (Sigma C-IOO). Either (a) $5 \mathrm{~mm}-\mathrm{NaClO}_{3}$ or $(b) 5 \mathrm{~mm}-\mathrm{NaNO}_{3}$ was included as the terminal electron acceptor. Cell suspension ( $2 \mathrm{ml}$, containing $57 \mathrm{mg}$ dry wt bacteria), $\mathrm{H}_{2} \mathrm{O}_{2}$, Triton $\mathrm{X}-\mathrm{I} 00(0.08 \%)$ and sodium azide $(100 \mu \mathrm{M})$ were added as indicated. The rates of reduction given alongside the traces are expressed in $\mu \mathrm{g}$-atom oxygen $\mathrm{s}^{-1}(\mathrm{~g} \text { dry wt})^{-1}(---)$ and $\mu \mathrm{mol}$ nitrate or chlorate $\mathrm{s}^{-1}(\mathrm{~g} \text { dry wt })^{-1}$ $(-)$.

was no longer available there was little acceleration in the rate of nitrate reduction (Fig. 3). Addition of nitrate to the membrane vesicles decreased the rate of oxygen uptake by $50 \%$. A subsequent addition of azide $(100 \mu \mathrm{M})$, a potent inhibitor of the nitrate reductase in $P$. denitrificans (Forget, 1971), abolished nitrate reduction and resulted in a rate of oxygen uptake similar to that observed in the absence of nitrate.

Thus, in intact cells of $\boldsymbol{P}$. denitrificans, reducing equivalents are directed preferentially to oxygen, while in membrane vesicles reducing equivalents are distributed equally to oxygen and nitrate. The reason for this difference between the intact cells and the membrane vesicles is not yet known. 


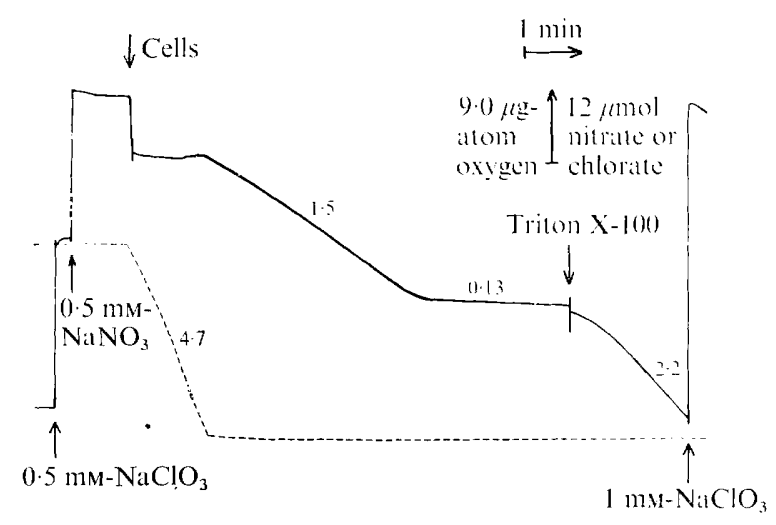

Fig. 6. Reduction of nitrate and chlorate by $P$. denitrificans. The reaction mixture contained $200 \mathrm{~mm}-$ sucrose, $20 \mathrm{~mm}$-Tris $/ \mathrm{HCl}\left(\mathrm{pH} 8 \cdot 0\right.$ ), Io mM-sodium succinate, $4 \mathrm{~mm}-\mathrm{NaClO}_{3}$, and $5 \mu \mathrm{l}$ catalase (Sigma C-100). Additions of $0.5 \mathrm{~mm}-\mathrm{NaClO}_{3}, 0.5 \mathrm{~mm}-\mathrm{NaNO}_{3}$, cell suspension ( $2 \mathrm{ml}$, containing $75 \mathrm{mg}$ dry wt bacteria), $0.08 \%$ Triton $\mathrm{X}-100$, and $\mathrm{I} \mathrm{mm}-\mathrm{NaClO}_{3}$ were made as indicated. The rates of reduction given alongside the traces are expressed in $\mu \mathrm{g}$-atom oxygen $\mathrm{s}^{-1}(\mathrm{~g} \text { dry wt })^{-1}(---)$ and $\mu \mathrm{mol}$ nitrate or chlorate $\mathrm{s}^{-1}(\mathrm{~g} \text { dry wt })^{-1}(-)$.

\section{Utilization of nitrate by $E$. coli}

With succinate as substrate, $E$. coli behaved like $P$. denitrificans, with nitrate respiration ceasing when oxygen was introduced into the medium and equally rapidly recommencing when the reaction medium became depleted of oxygen (Fig. $4 a$ ). By contrast, with formate as substrate, an appreciable rate of nitrate reduction was observed in the presence of oxygen, albeit at a slower rate than that observed in the absence of oxygen (Fig. $4 b$ ). The rate of oxygen uptake with formate was however Io times faster than with succinate (Fig. 4). Thus the unusual aerobic nitrate reduction by the E. coli oxidizing formate may be due to a spillover of reducing equivalents from the reduced quinone to the nitrate reductase.

\section{Utilization of chlorate by $P$. denitrificans}

The nitrate reductase isolated from $P$. denitrificans, like that from other bacteria, can reduce chlorate as effectively as nitrate (Forget, 1971). Generally, when chlorate is added to anaerobic cultures of bacteria able to reduce nitrate, the chlorate is reduced to the toxic chlorite by the nitrate reductase. Thus only those mutants unable to reduce nitrate are resistant to chlorate (see Payne, 1973). However intact cells of $P$. denitrificans unexpectedly reduced chlorate only one tenth as fast as they reduced nitrate (Fig. $5 a$ ), though addition of Triton X-IOO (Fig. $5 a$ ) gave an even higher rate of chlorate reduction than the rate of nitrate reduction (Fig. $5 b$ ). Additions of Triton X-I00 inhibited nitrate reduction slightly (Fig. $5 b$ ) and nitrite reduction severely.

When intact cells were added to a medium containing $4.5 \mathrm{~mm}$-chlorate and $0.5 \mathrm{~mm}$ nitrate, all of the nitrate was reduced (under anaerobic conditions), but little reduction of the residual chlorate occurred until Triton X-100 was added (Fig. 6).

In contrast to intact cells, membrane vesicles of $P$. denitrificans reduced chlorate and nitrate at similar rates, with either succinate or NADH as substrate (Table I). The preparations of membrane vesicles used in the present study have been shown previously (Burnell et al., 1975) to consist predominantly of 'inside-out' membrane vesicles, in which the orientation of the vesicle membrane is the reverse of that of the plasma membrane in the intact cell. 
Table I. Reduction of chlorate and nitrate by membrane vesicles of

$$
P \text {. denitrificans }
$$

The reaction mixture contained $20 \mathrm{~mm}-\mathrm{Tris} / \mathrm{HCl}(\mathrm{pH} 8 \cdot 0)$, and either $5 \mathrm{~mm}-\mathrm{NaNO}_{3}$ or $5 \mathrm{~mm}-\mathrm{NaClO}_{3}$. When succinate was the substrate, Io mM-sodium succinate and I $18 \mathrm{mg}$ vesicle membrane protein were added. When NADH was the substrate, $0.6 \mathrm{ml}$ ethanol, $0.6 \mathrm{mM}_{-\mathrm{NAD}}^{+}, 2 \mathrm{mg}$ alcohol dehydrogenase (about 800 units), $30 \mathrm{~mm}$-ammonium acetate, $0.5 \mu \mathrm{g}$ gramicidin $\mathrm{D}$, and $6.4 \mathrm{mg}$ vesicle membrane protein were added. Rates of oxygen reduction are expressed as $\mu \mathrm{g}$-atom $\mathrm{min}^{-1}$ (mg protein $)^{-1}$ and rates of nitrate and chlorate reduction as $\mu \mathrm{mol} \mathrm{min}^{-1}$ (mg protein) ${ }^{-1}$.

Terminal electron acceptors offered

$$
\begin{aligned}
& \mathrm{O}_{2}+\mathrm{NO}_{3}^{-} \\
& \mathrm{O}_{2}+\mathrm{ClO}_{3}^{-}
\end{aligned}
$$

Substrate
$\left\{\begin{array}{l}\text { Succinate } \\ \text { NADH }\end{array}\right.$
$\left\{\begin{array}{l}\text { Succinate } \\ \text { NADH }\end{array}\right.$

Rates of reduction

$\begin{array}{ccc}\mathrm{O}_{2} & \mathrm{NO}_{3}^{-} & \mathrm{ClO}_{3}^{-} \\ 0.88 & \mathrm{I} .85 & - \\ 2.40 & 2.67 & - \\ 0.68 & - & \mathrm{I} .88 \\ \mathrm{I} \cdot 75 & - & 3.62\end{array}$

The simplest explanation for the observation that intact cells could not reduce chlorate, while inside-out membrane vesicles could, requires (i) that the nitrate reductase is orientated in the plasma membrane so that nitrate approaches the nitrate reductase from the cell cytosol, (ii) that a nitrate carrier permits nitrate entry across the plasma membrane, and (iii) that this carrier is unable to transport chlorate. Triton X-100 presumably destroys the integrity of the plasma membrane of intact cells and thus enables chlorate to gain access to the nitrate reductase whereas both nitrate and chlorate gain free access to the nitrate reductase externally orientated in the membrane of the inside-out vesicles. An internal orientation of the nitrate reductase in $\boldsymbol{P}$. denitrificans is compatible with the previous observation of oxidative phosphorylation and 'respiratory control' associated with nitrate reduction by inside-out vesicles of $P$. denitrificans (John \& Whatley, 1970). However, there is as yet no direct evidence of the sort provided by lactoperoxidase-catalysed iodination for the orientation of the nitrate reductase molecule, nor is there direct evidence for the presence of a nitrate carrier. By contrast, for $E$. coli there is a considerable body of evidence to indicate (i) that the nitrate reductase complex spans the plasma membrane in such a way that nitrate approaches the enzyme directly from the external medium, and (ii) that a nitrate carrier is absent (Kemp, Haddock \& Garland, 1975; Garland, Downie \& Haddock, I975; Boxer \& Clegg, 1975).

I wish to thank Professor F. R. Whatley for his interest in the work and for critical comments on the manuscript. Financial support was provided by the Science Research Council.

\section{REFERENCES}

BOXER, D. H. \& ClEGG, R. A. (1975). A transmembrane location for the proton-translocating reduced ubiquinone $\rightarrow$ nitrate reductase segment of the respiratory chain of Escherichia coli. FEBS Letters $6 \mathbf{0}$, $54-57$.

Burnell, J. N., John, P. \& Whatley, F. R. (I975). The reversibility of active sulphate transport in membrane vesicles of Paracoccus denitrificans. Biochemical Journal I50, 527-536.

Davis, D. H., Doudoroff, M., Stanier, R. Y. \& Mandel, M. (1969). Proposal to reject the genus Hydrogenomonas: taxonomic implications. International Journal of Systematic Bacteriology r9, 375-390.

Delwiche, C. C. (1956). Denitrification. In Inorganic Nitrogen Metabolism, pp. 233-256. Edited by W. D. McElroy and B. Glass. Baltimore: The Johns Hopkins Press.

Forget, P. (I97I). Les nitrate-réductases bactériennes. Solubilisation, purification et propriétés de l'enzyme A de Micrococcus denitrificans. European Journal of Biochemistry 18, 442-450. 
Garland, P. B., Downie, J. A. \& Haddock, B. A. (1975). Proton translocation and the respiratory nitrate reductase of Escherichia coli. Biochemical Journal 152, 547-559.

JoHN, P. \& WHATLEY, F. R. (1970). Oxidative phosphorylation coupled to oxygen uptake and nitrate reduction in Micrococcus denitrificans. Biochimica et biophysica acta 216, 342-352.

John, P. \& WHATLEY, F. R. (1975). Paracoccus denitrificans and the evolutionary origin of the mitochondrion. Nature, London, 254, 495-498.

Kaye, G. W. C. \& LABY, T. H. (1966). Tables of Physical and Chemical Constants, I3th edn. London: Longmans.

Kemp, M. B., Haddock, B. A. \& Garland, P. B. (1975). Synthesis and sidedness of membrane-bound respiratory nitrate reductase (EC I.7.99.4) in Escherichia coli lacking cytochromes. Biochemical Journal 148, 329-333.

LAM, Y. \& Nicholas, D. J. D. (1969). A nitrite reductase with cytochrome oxidase activity from Micrococcus denitrificans. Biochimica et biophysica acta $180,459-472$.

Lowry, O. H., Rosebrough, N. J., FarR, A. L. \& Randall, R. J. (I95I). Protein measurement with the Folin phenol reagent. Journal of Biological Chemistry 193, 265-275.

Newton, N. (1969). The two-haem nitrite reductase of Micrococcus denitrificans. Biochimica et biophysica acta 185, 316-331.

PAYNE, W. J. (1973). Reduction of nitrogenous oxides by micro-organisms. Bacteriological Reviews 37, 409452.

WhITE, D. C. \& Sinclair, P. R. (I97I). Branched electron-transfer systems in bacteria. Advances in Microbial Physiology 5, 173-2II. 